\title{
Isolasi dan identifikasi Escherichia coli dari Sumber Air Minum Kandang Broiler serta Uji Aktivitas Antibakteri Lidah Buaya
}

\section{Isolation and Identification of Escherichia coli form Broiler Farm Water Source and Aloe Vera Antibacterial Activity Test}

\author{
Dian Meidididewi Nuraini ${ }^{1) *}$, Morsid Andityas²), Adi Paramarta ${ }^{3)}$, Nur Rohman Najib ${ }^{3)}$, \\ Agustina Dwi Wijayanti ${ }^{4}$ \\ ${ }^{1)}$ Program Studi Peternakan, Fakultas Pertanian, Universitas Sebelas Maret \\ Jl. Ir. Sutami, Surakarta 57126. Indonesia \\ ${ }^{2)}$ Diploma Kesehatan Hewan, Departemen Teknologi Hayati dan Veteriner, Sekolah Vokasi, \\ Universitas Gadjah Mada \\ 3) Fakultas Kedokteran Hewan, Universitas Gadjah Mada \\ 4) Departemen Farmakologi, Fakultas Kedokteran Hewan, Universitas Gadjah Mada \\ Jl. Fauna No. 2, Sleman, Yogyakarta 55281. Indonesia
}

Article history

Received: Jun 17, 2020;

Accepted: Aug 8, 2020

* Corresponding author:

E-mail:

dianmeididewi@gmail.com

DOI::

10.46549/jipvet.v10i2.116
Abstract

Colibacillosis is one of the most problematic issues in the boiler industry. However, the antibiotic overuse has induced Escherichia coli resistance so that other alternative to reduce colibacillosis is needed. One of the alternatives is using aloe vera (Aloe barbadensis Miller), which has been widely used as an antibacterial agent. This study aims to isolate and identify $E$. coli from the broiler drinking water source and test the aloe vera antibacterial activity against it. Escherichia coli were isolated from well in three broiler farms in Moyudan District, Sleman, Yogyakarta that previously had colibacillosis. Escherichia coli were isolated using eosin methylene blue (EMB) agar and the metallic sheen colony was tested to confirm the biochemist reaction. The pure isolate of $E$. coli was used in the aloe vera inhibition test using Muller Hinton agar (MHA) by a Well Diffusion method. Aloe vera was processed using aquades and ethanol $70 \%$. The aquades infusion was diluted into $12.5 \%, 25 \%, 50 \%, 75 \%$, and $100 \%$ and the extract ethanol $70 \%$ was diluted into $10 \%, 12.5, \%, 25 \%, 40 \%$, and $50 \%$. The bacterial identification showed that one of three samples contained E. coli which was then used for inhibition test. The result showed no inhibition zone in the aquades infusion while ethanol extract showed an inhibition zone in concentration $25 \%, 40 \%$, and $50 \%$ of aloe vera extract with a diameter $19.5 \mathrm{~mm}, 24 \mathrm{~mm}$, and 25 $\mathrm{mm}$. It can be concluded that aloe vera ethanol extract has inhibitory activity against $E$. coli in poultry drinking water with a minimum concentration of $25 \%$.

Keywords: Aloe vera; Broiler drinking water; Escherichia coli; Inhibitory activity

\section{Abstrak}

Colibacilosis masih menjadi permasalahan dalam industri broiler. Penggunaan antibiotik berlebihan telah menyebabkan resistensi sehingga perlu alternatif lain. Salah satu alternatif adalah menggunakan bahan alami seperti adalah lidah buaya (Aloe barbadensis Miller) yang memilliki aktivitas antibakteri. Penelitian ini bertujuan untuk mengisolasi dan mengidentifikasi E. coli dari sumber air minum di kandang broiler serta menguji aktivitas inhibisi lidah buaya terhadap bakteri tersebut. Air yang digunakan sebagai sumber E. coli berasal dari sumur di tiga peternakan broiler di Kecamatan Moyudan, Sleman, Yogyakarta yang memiliki riwayat infeksi colibacilosis. Bakteri E. coli diisolasi menggunakan media eosin methylene blue (EMB) dan diuji sifat biokimia untuk mengkonfirmasi sifat bakteri $E$. coli. Isolat murni $E$. coli digunakan pada uji daya hambat bakteri 
dengan metode difusi sumuran menggunakan media Muller Hinton Agar (MHA). Lidah buaya diproses menggunakan aquades dan ethanol $70 \%$. Infusa aquades diencerkan menjadi konsentrasi 12,5\%, 25\%, 50\%, 75\%, dan $100 \%$ dan ekstrak ethanol $70 \%$ diencerkan menjadi $10 \%, 12 ., \%, 25 \%, 40 \%$, dan $50 \%$. Hasil isolasi menunjukan bahwa satu sumber air dari sumur di Desa Kolowenang mengandung E. coli yang kemudian digunakan pada pengujian daya hambat. Hasil pengujian menunjukan tidak ada daya hambat yang terbentuk pada infusa aquades sedangkan ekstrak etanol lidah buaya 25\%, 40\%, dan 50\% menunjukan adanya zona hambat sebesar 19,5 mm, $24 \mathrm{~mm}$, dan $25 \mathrm{~mm}$ berturut-turut. Ekstrak etanol lidah buaya pada penelitian ini memiliki kemampuan menghambat pertumbuhan E. coli yang bersumber dari air minum broiler dengan konsentrasi terendah $25 \%$.

Kata kunci: Air minum broiler; Escherichia coli; Lidah buaya; Daya hambat bakteri

\section{PENDAHULUAN}

Kasus colibacilosis pada peternakan ayam broiler masih sering ditemukan. Colibacilosis merupakan penyakit akibat infeksi Eschericia coli yang menyebabkan airsaculitis, omphalitis, pericarditis, hepatitis dan enteritis (Wahyuwardan et al., 2014). Escherichia coli dilaporkan sebagai penyebab infeksi pada unggas sebanyak 22,2\% (Wiedosari dan Wahyuwardani, 2015). Berdasarkan bedah bangkai dari ayam mati di Yogyakarta dan Bogor, E. coli diisolasi $75-100 \%$ (Wahyuwardan et al., 2014). Kejadian ini mengindikasikan bahwa colibacilosis banyak terjadi pada industri perunggasan. Bakteri $E$. coli dapat ditemukan sebagai bakteri di saluran pencernaan dan lingkungan. Keberadaan bakteri E. coli pada air minum maupun sumber air minum biasa digunakan sebagai indikator adanya pencemaran air yang menyebabkan penurunan kualitas air minum (Besung et al., 2017; Lusandika et al., 2017). Pencemaran air minum dimulai dari sumber air sampai penampungan air (Lusandika et al., 2017). Air yang tercemar $E$. coli dikhawatirkan dapat menyebabkan penyebaran bakteri dan menyebabkan penyakit.

Beberapa cara telah dilakukan untuk mencegah pertumbuhan bakteri E. coli yang mencemari pakan dan air minum dengan pemberian antibiotik. Penggunaan antibiotik berlebihan menyebabkan resistensi E. coli. Escherichia coli yang diisolasi dari peternakan unggas memiliki resistensi terhadap beberapa antibiotik dengan tingkat insidensi yang tinggi (Wibisono et al., 2020). Resistensi memiliki dampak negatif bagi manusia maupun hewan karena kekebalan bakteri terhadap antibiotik tertentu dapat menghambat proses pengobatan dan kesembuhan (Utami, 2012). Beberapa antibiotik yang resisten terhadap E. coli antara lain tetrasiklin, sulfametoxazole, trimethoprim, ampicillin, asam nalidixic, ciprofloxacin, enrofloxcin, gentamicin, dan chloramphenicol (Niasono et al., 2019; Wibisono et al., 2020). Kondisi tersebut meningkatkan tantangan peternak dalam menghadapi infeksi colibacilosis serta menyebabkan pencemaran. Penggunaan antibiotik sebagai feed additive sudah dilarang melalui Peraturan Menteri Pertanian Nomor 14 Tahun 2017 tentang Klasifikasi Obat Hewan. Hal ini menyebabkan kebutuhan alternatif pencegahan $E$. coli pada peternakan ayam broiler. Alternatif yang dapat dilakukan adalah dengan memanfaattkan bahan-bahan herbal alami yang memiliki daya antibakteri.

Penggunaan bahan alami sebagai pengganti obat-obatan kimia banyak diterapkan di Indonesia, termasuk pada dunia perunggasan. Bahan yang sering digunakan adalah lidah buaya. Lidah buaya diketahui memiliki berbagai zat aktif yang diketahui dapat menghambat pertumbuhan bakteri (Yebpella et al., 2011; Sulistyani et al., 2016; Rahardjo et al., 2017). Berbagai mikroba dapat dihambat pertumbuhannya oleh lidah buaya seperti Staphylococus aureus, Enterobacter faecalis, Streptococcus mutans, Candida albicans, Mycobacterium smegmatis, dan Klebsiella pneumonia serta $E$. coli dari manusia (Aswarita, 2013; Rahardjo et al., 2017; Agrawal et al., 2018). Efektivitas lidah buaya dalam menghambat pertumbuhan E. coli 
sumber air minum broiler belum diketahui. Bakteri E. coli pada unggas memilliki strain yang berbeda dengan strain manusia. Penelitian ini bertujuan untuk melihat efektivitas ekstrak lidah buaya untuk menghambat $E$. coli yang diisolasi dari sumber air minum ayam broiler.

\section{MATERI DAN METODE}

\section{ISOLASI ESCHERICHIA COLI}

Sampel air diambil dari tiga lokasi peternakan di Dusun Kolowenang, Dusun Pingitan, dan Dusun Pakelan, Kecamatan Moyudan, Kabupaten Sleman, Yogyakarta. Sebanyak $10 \mathrm{ml}$ air ditampung dalam tabung steril dan disimpan pada ice box selama transportasi. Isolasi $E$. coli dilakukan berdasarkan metode Arshad et al. (2006). Secara singkat, satu Ose air dari tabung steril dan ditanam pada media Eosin Methylene Blue (EMB) (Oxoid CM0069) dan dinkubasi pada suhu $37^{\circ} \mathrm{C}$ selama 24 jam. Koloni metallic sheen yang tumbuh pada EMB diuji biokimia menggunakan media triple sugar iron (TSI), indol, methyl red, voges proskauer, sitrat (IMViC), urea, glukosa, sukrosa dan laktosa untuk mengkonfirmasi sifat biokimia bakteri tersebut.

\section{WAKTU DAN TEMPAT PENELITIAN}

Penelitian ini dilaksanakan pada Bulan April-Juni 2013. Isolasi, identifikasi E. coli, pembuatan infusa lidah buaya, dan pengujian aktivitas antibakteri lidah buaya dilakukan di Laboratorium Mikrobiologi, Fakultas Kedokteran Hewan, Universitas Gadjah Mada. Pembuatan ekstrak ethanol $70 \%$ dilakukan oleh laboran di Laboratorium Farmakologi, Fakultas Farmasi, Universitas Gadjah Mada.

\section{PEMBUATAN INFUSA LIDAH BUAYA}

Sebanyak $1 \mathrm{~kg}$ lidah buaya dari pasar lokal di daerah Yogyakarta digunakan dalam proses pembuatan infusa. Metode yang digunakan merupakan modifikasi dari Zeb (2006). Secara singkat, infusa aquades dibuat dengan cara merendam lidah buaya dalam air selama satu malam kemudian dihancurkan dengan blender sampai terbentuk bentukan gel pekat. Gel pekat tersebut kemudian disaring menggunakan kertas saring steril dan disimpan dalam tabung steril. Gel ini dinyatakan sebagai konsentrasi $100 \%$.

\section{PENGENCERAN INFUSA DAN EKSTRAK ETHANOL 70\% LIDAH BUAYA}

Pengenceran infusa dilakukan dengan cara mencampur infusa $100 \%$ dengan aquades menjadi konsentrasi $12,5 \%, 25 \%, 50 \%$, dan $75 \%$. Konsentrasi tersebut dipilih setelah prepenelitian menunjukan bahwa konsentrasi hingga $10 \%$ tidak menunjukan aktivitas antibakterial. Ekstrak lidah buaya yang didapatkan dari Laboratorium Farmasi diencerkan menggunakan aquades menjadi konsentrasi $10 \%, 12,5 \%, 25 \%, 40 \%$, dan $50 \%$ dan disimpan dalam tabung steril. Konsentrasi tersebut dipilih mengikuti hasil penelitian terdahulu yang menunjukan konsentrasi optimal 25\%, sehingga konsentrasi tersebut digunakan sebagai nilai tengah (Aswarita, 2013)

\section{UJI DAYA HAMBAT BAKTERI}

Pengujian daya hambat ekstrak lidah buaya dilakukan dengan metode difusi pada dua media agar Mueller Hinton (MHA) (Oxoid CM0337). Isolat E. coli diencerkan dengan $\mathrm{NaCl}$ 0,9\% sampai memiliki kekeruhan yang sama dengan McFarland 0,5. Selanjtunya, dari masing-masing pengenceran ditanam pada media MHA yang telah dilubangi. Masingmasing sumuran kemudian diisi dengan $0,1 \mathrm{ml}$ ekstrak lidah buaya dengan pengenceran yang berbeda. Selanjutnya media diinkubasi pada suhu $37^{\circ} \mathrm{C}$ selama 24 jam (Valgas et al., 2007). Diameter zona hambat dari masing-masing pengenceran ekstrak lidah buaya diukur dengan penggaris dan dinyatakan dalam $\mathrm{mm}$.

\section{HASIL DAN PEMBAHASAN}

Terdapat berbagai jenis bakteri dari sampel sumber air minum yang tumbuh pada media EMB yang ditampilkan pada Tabel 1. Media EMB mengandung pewarna eosin $Y$ dan methylene blue yang merupakan indikator $\mathrm{pH}$ dan penghambat pertumbuhan bakteri Gram positif. Kondisi asam yang sangat tinggi akibat fermentasi laktosa akan membentuk presipitat metallic sheen kehijauan yang hanya dihasilkan oleh E. coli. Bakteri lain yang juga memfermentasi laktosa dan menyebabkan kondisi asam akan menghasilkan koloni keunguan. Bakteri yang memfermentasikan laktosa akan menunjukan pertumbuhan koloni 
transparan atau jika menghasilkan asam yang lemah maka akan menunjukan koloni merah muda (Leininger et al., 2001). Koloni metallic sheen hanya ditemukan pada media EMB dari sampel sumber air minum ayam broiler Desa
Kolowenang. Koloni metallic sheen terebut menunjukan pada sampel air tersebut terdapat cemaran E. coli yang selanjutnya dikonfirmasi melalui uji biokimia (Tabel 2).

Tabel 1. Jenis koloni bakteri yang tumbuh pada media EMB dari sampel sumber air minum ayam broiler

\begin{tabular}{lcccc}
\hline \multirow{2}{*}{ Asal Sampel } & \multicolumn{5}{c}{ Tipe Koloni } \\
\cline { 2 - 5 } & Transparan & Merah Muda & Keunguan & Metallic sheen \\
\hline Kolowenang & ++ & - & +++ & ++ \\
Pingitan & + & +++ & + & - \\
Pakelan & +++ & + & +++ & - \\
\hline
\end{tabular}

Keterangan: +: sedikit; ++: banyak; +++: sangat banyak

Tabel 2. Hasil uji biokimia isolat murni Escherichia coli

\begin{tabular}{lcc}
\hline \multicolumn{1}{c}{ Media } & Hasil Uji & Sifat Escherichia coli* \\
\hline Indol & + & + \\
Methyl red & + & + \\
Voges proskauer & - & - \\
Citrat & - & - \\
Urea & - & - \\
Glukosa & + (gas) & + (gas $)$ \\
Sukrosa & + & + \\
Laktosa & + & d \\
\hline
\end{tabular}

*(Sumber: Hansen \& Nielsen 2014)

Escherichia coli merupakan bakteri komensal yang hidup pada saluran intestinal hewan maupun manusia dan umum ditemukan pada feses (Niasono et al., 2019). Oleh karena itu, deteksi pencemaran oleh feses dapat dilakukan dengan identifikasi E. coli, termasuk pencemaran pada air (Furtula et al., 2010). Bakteri E. coli yang termasuk dalam kelompok coliform dapat ditemukan pada sumber air minum, tempat penampungan, maupun tempat minum ternak (Suarjana, 2009). Coliform pada air dapat berasal dari kontaminasi kotoran ternak maupun manusia yang disebabkan oleh kegiatan manusia di sekitar sumber air yang kurang menjaga higienitas (Suarjana, 2009). Pencemaran E. coli bisa disebabkan oleh terbawanya feses pada peralatan kandang yang kemudian terbawa hingga sumur. Hal tersebut diperkuat oleh temuan E. coli terisolasi dari alas kaki yang digunakan untuk pada peternakan broiler (Niasono et al., 2019). Penemuan coliform di air sumur pada penelitian ini mengindikasikan bahwa terdapat pencemaran pada sumur tersebut yang diakibatkan sanitasi dan higienitas yang kurang baik sehingga bakteri dapat masuk ke dalam sumber air.

Hasil uji daya hambat menggunakan infusi aqudes lidah buaya menunjukan tidak ada zona hambat yang terbentuk pada semua konsentrasi (Tabel 3). Ekstrak etanol lidah buaya menunjukan diameter sebesar 19,5 mm, $25 \mathrm{~mm}$, dan $25 \mathrm{~mm}$ pada konsentrasi 25\%, 40\%, dan $50 \%$ berturut-turut seperti yang tertera pada Tabel 4. Perbedaan hasil kemampuan daya hambat $E$. coli dapat disebabkan oleh beberapa faktor, salah satunya adalah perbedaan pelarut yang digunakan. Pelarut yang digunakan sebagai pelarut ekstrak berpengaruh sangat nyata terhadap kandungan aktif pada ekstrak dimana infusa aquades memiliki jumlah fenol yang lebih rendah dibandingkan ethanol $70 \%$. Fenol merupakan zat yang dapat menjaga komponen aktif yang terkandung pada ekstrak tanaman dari oksidasi (Mulyanita, 2019). Kadar zat aktif pada infusa aquades menurun dikarenakan oksidasi akibat lama terpapar oleh udara (Rahardjo et al., 2017). Perlakuan infusa aquades pada penelitian ini mengalami oksidasi pada saat pemrosesan karena memakan waktu 
yang cukup lama sehingga menghilangkan zat aktif yang dapat menghambat pertumbuhan bakteri.

Kandungan aktif lidah buaya dapat dipengaruhi oleh perbedaan geografis lokasi pertumbuhan lidah buaya (Yebpella et al., 2011). Lidah buaya pada penelitian ini didapatkan dari pasar lokal yang dipesan khusus dari satu lokasi pertanian. Perbedaan komponen zat aktif karena perbedaan unsur hara tanah di lokasi pertumbuhan tanaman bukan menjadi penyebab perbedaan hasil pada dua metode ekstraksi. Jenis materi, seperti gel tanpa kulit atau daun lidah buaya keseluruhan juga berpengaruh terhadap komponen metabolit lidah buaya. Ekstrak keseluruhan daun lidah buaya memiliki kemampuan hambat bakteri lebih baik dibandingkan dengan ekstrak gel lidah buaya tanpa kulit (Agrawal et al., 2018). Ekstraksi dengan akuades menyebabkan banyak ampas yang tersisa pada saat proses penyaringan sehingga mayoritas kulit lidah buaya tidak terbawa pada ekstrak tersebut. Hal ini menyebabkan penurunan kandungan metabolit sehingga menurunkan kemampuan hambat bakteri.

Tabel 3. Daya hambat infusa lidah buaya

\begin{tabular}{cccc}
\hline Pengenceran & Zona hambat 1 $(\mathbf{m m})$ & Zona hambat 2 $(\mathbf{m m})$ & Rata-rata $(\mathbf{m m})$ \\
\hline $12,5 \%$ & - & - & - \\
$25 \%$ & - & - & - \\
$50 \%$ & - & - & - \\
$75 \%$ & - & - & - \\
$100 \%$ & - & - & - \\
\hline
\end{tabular}

Tabel 4. Daya hambat ekstrak ethanol lidah buaya

\begin{tabular}{cccc}
\hline Pengenceran & Zona hambat 1 $\mathbf{( m m})$ & Zona hambat 2 (mm) & Rata-rata $(\mathbf{m m})$ \\
\hline $10 \%$ & - & - & - \\
$12,5 \%$ & - & - & - \\
$25 \%$ & 21 & 18 & 19,5 \\
$40 \%$ & 22 & 26 & 24 \\
$50 \%$ & 22 & 28 & 25 \\
\hline
\end{tabular}

Hasil pada ekstrak ethanol lidah buaya pada penelitian ini sejalan dengan berbagai penelitian lain termasuk Rahayu (2006), Aswarita (2013), Stanley et al. (2014), dan Widyastuti et al. (2019). Hasil dari penelitianpenelitian tersebut menunjukan variasi pada konsentrasi minimal yang dapat menghambat pertumbuhan E. coli. Aswarita (2013) melaporkan konsentrasi minimal yang sama dengan penelitian ini dimulai pada konsentrasi $25 \%$, namun studi lain melaporkan zona hambat yang terbentuk dimulai dari konsentrasi $75 \%$ (Rahayu, 2006).

Lidah buaya memiliki kandungan zat aktif seperti saponin, alkaloid, glikosida, tannin, antraquinon, protein dan flavonoid (Yebpella et al., 2011). Kandungan zat aktif tersebut memiliki kemampuan menghambat pertumbuhan mikroorganisme patogen (Freeman and Beattie, 2008). Tannin dan flavonoid memiliki kemampuan menghambat pertumbuhan bakteri. Tannin dapat membentuk ikatan kompleks dengan protein yang kaya proline yang mengakibatkan penghambatan sisntesis dinding sel bakteri melalui inaktivasi adhesin bakteri (Igbinosa et al., 2009; Suryati et al., 2018). Flavonoid pada lidah buaya dapat menghambat dan melisiskan dinding sel bakteri (Suryati et al., 2018). Senyawa lain yang memiliki aktivitas antibakteri pada lidah buaya adalah antraquinon. Antrakuinon menginaktivasi protein bakteri melalui ikatan antrakuinon (Rahardjo et al., 2017). Zat-zat ini beperan dalam aktivitas inhibisi ekstrak ethanol lidah buaya pada penelitian ini sehingga membentuk zona hambat pada media MHA.

\section{KESIMPULAN}

Hasil isolasi dan identifikasi menunjukan sumber air minum dari Desa Kolowenang 
mengandung E. coli. Infusa lidah buaya tidak memiliki daya hambat terhadap pertumbuhan E. coli. Ektrak ethanol $70 \%$ lidah buaya menunjukan zona hambat pada konsentrasi $25 \%, 40 \%$, dan $50 \%$ dengan peningkatan zona hambat pada konsentrasi yang lebih tinggi.

\section{DAFTAR PUSTAKA}

Agrawal P., Kotagiri D. dan Kolluru V. 2018 Comparative Analysis of Antimicrobial Activity of Herbal Extracts against Pathogenic Microbes. Advances of Biochemistry and Biotechnology. (2):1-7. DOI: 10.29011/2574-7258. 000063.

Arshad R., Farooq S., and Ali S. S. 2006. Manipulation of different media and methods for cost-effective characterization of Escherichia coli strains collected from different habitats. Pakistan Journal of Botany, 38(3):779.

Aswarita R. 2013. Interaksi ekstrak daun lidah buaya (Aloe vera L.) dan daun jambu biji (Psidium guajava L.) terhadap daya hambat Escherichia coli secara in vitro. Jurnal Edubio Tropika. 1(2):115-120.

Besung I. N. K., Putra I. P. Y. P. dan Suarjana I. G. K. 2017. Total Bakteri pada Air minum di Peternakan Ayam Pedaging Desa Mengesta Kecamatan Penebel Kabupaten Tabanan. Buletin Veteriner Udayana. 1(2):145-149.

Freeman B. C. dan Beattie G. A. 2008. An overview of plant defenses against pathogens and herbivores. The Plant Health Instructor. DOI: 10.1094/PHI-I2008-0226-01.

Furtula V., Farrell E., Diarrassouba F., Rempel H., Pritchard J. dan Diarra M. 2010. Veterinary pharmaceuticals and antibiotic resistance of Escherichia coli isolates in poultry litter from commercial farms and controlled feeding trials. Poultry Science 89:180-8. DOI: 10.3382/ps.2009-00198.

Hansen A. K. dan Nielsen D. S. 2014. Handbook of Laboratory Animal Bacteriology. Boa Raton: CRC Press.

Igbinosa O., Igbinosa E. dan Aiyegoro O. 2009. Antimicrobial activity and phytochemical screening of stem bark extracts from Jatropha curcas (Linn). African journal of pharmacy and pharmacology 3(2):58-62.
Leininger D. J., Roberson J. R., Elvinger F. 2001. Use of eosin methylene blue agar to differentiate Escherichia coli from other gram-negative mastitis pathogens. Journal of veterinary diagnostic investigation, 13(3):273-275.

Lusandika E. H., Suarjana I. G. K. dan Suada I. K. 2017. Kualitas air peternakan ayam broiler ditinjau dari jumlah bakteri coliform dan Escherichia coli. Buletin Veteriner Udayana 9(1):81-86. DOI: 10.21531/bulvet.2017.9.1.81.

Mulyanita M. 2019. Total fenol, flavonoid dan aktivitas antimikroba ekstrak limbah kulit lidah buaya (Aloe chinensis Baker). Jurnal Vokasi Kesehatan 5:95-102.

Niasono A. B., Latif H. dan Purnawarman T. 2019. Resistensi antibiotik terhadap bakteri Escherichia coli yang diisolasi dari peternakan ayam pedaging di Kabupaten Subang Jawa Barat. Jurnal Veteriner, 20(2):187-195. DOI: 10.19087/jveteriner.2019.20.2.187.

Rahardjo M., Koendhori E. B. dan Setiawati Y. 2017. Uji aktivitas antibakteri ekstrak etanol lidah buaya (Aloe vera) terhadap bakteri Staphylococcus aureus. Jurnal Kedokteran Syiah Kuala 17(2):65-70. DOI: $10.24815 / \mathrm{jks} . v 17 \mathrm{i} 2.8975$.

Rahayu I. 2006. Aloe barbadensis Miller and Aloe chinensis Baker as antibiotic in medication of poultry etnoveteriner by in vitro. Journal of Protein. 13(1):31-34.

Suarjana I. G. K. 2009. Kualitas air minum ternak ayam petelur di Desa Piling Kecamatan Penebel Kabupaten Tabanan ditinjau dari jumlah bakteri coliform. Buletin Veteriner Udayana. 1(2): 55-60.

Sulistyani N., Kurniati E. dan Cempaka R. A. 2016. Antibacterial activity of aloe vera leaf infuse (Aloe barbadensis Miller). Jurnal Penelitian Saintek. 21(2): 120-128. DOI: 10.21831/jps.v21i2.13942.

Suryati N., Bahar E. dan Ilmiawati I. 2018. Uji Efektivitas antibakteri ekstrak aloe vera terhadap pertumbuhan Escherichia coli secara in vitro. Jurnal kesehatan Andalas. 6(3): $\quad 518-522$. DOI: $10.25077 /$ jka.v6i3.732.

Utami E. R. 2012. Antibiotika, resistensi, dan rasionalitas terapi. Sainstis. 1(1):124-138. DOI:10.18860/sains.v0i0.1861 
Valgas C., Souza S. M., Smânia E. F., dan Smânia A. 2007. Screening methods to determine antibacterial activity of natural products. Brazilian journal of microbiology. $\quad 38(2): \quad 369-380$. DOI:10.1590/S151783822007000200034.

Wahyuwardan S., Noor S., Poeloengan M. dan Aryanti T. 2014. Kasus kolibasilosis pada peternakan ayam pedaging di Yogyakarta dan Bogor. Prosiding Seminar Nasional Teknologi Peternakan dan Veteriner. DOI: 10.14334/Pros.Semnas.TPV-2014-p.606610.

Wibisono F. J., Sumiarto B., Untari T., Effendi M. H., Permatasari D. A. dan Witaningrum A. M. 2020. Prevalensi dan analisis faktor risiko multidrug resistance bakteri Escherichia coli pada ayam komersial di Kabupaten Blitar. Jurnal Ilmu Peternakan dan Veteriner Tropis. 10(1):15-22. DOI: 10.46549/jipvet.v10i1.74.

Widyastuti Y., Yuliani N., Widhyastini I. M. 2019. Aktivitas antibakteri infusa daun lidah buaya (Aloe vera 1) terhadap pertumbuhan Staphylococcus aureus dan Escherichia coli. Jurnal Sains Natural. 6(1):33-43. DOI:10.31938/jsn.v6i1.253.

Wiedosari E. dan Wahyuwardani S. 2015. Studi kasus penyakit ayam pedaging di Kabupaten Sukabumi dan Bogor. Jurnal Kedokteran Hewan-Indonesian Journal of Veterinary Sciences. 9(1): 9-13. DOI: 10.21157/j.ked.hewan.v9i1.2777.

Yebpella G., Adeyemi H. M., Hammuel C., Magomya A., Agbaji A. dan Okonkwo E. 2011. Phtyochemical screening and comparative study of antimicrobial activity of Aloe vera various extracts. African Journal of Microbiology Research. 5(10): 1182-1187. DOI: 10.5897/AJMR10.818.

Zeb A. 2012. Effect of water based infusion of Aloe barbedensis, Pimpinella anisum, Berberis lycium, Trigonella foenumgraecum and Allium sativum on the performance of broiler chicks. Pakistan Veterinary Journal. 32(4): 539-596. 